\title{
Electrogenic $\mathrm{H}^{+}$pathway contributes to stimulus-induced changes of internal pH and membrane potential in intact neutrophils: role of cytoplasmic phospholipase $A_{2}$
}

\author{
Katalin SUSZTÁK, Attila MÓCSAI, Erzsébet LIGETI and András KAPUS* \\ Department of Physiology and Laboratory of Cellular and Molecular Physiology, Semmelweis University of Medicine, Budapest 8, P0 Box 259, H-1444, Budapest, \\ Hungary
}

\begin{abstract}
The potential role of cytosolic phospholipase $\mathrm{A}_{2}\left(\mathrm{cPLA}_{2}\right)$ in the regulation of the electrogenic arachidonic acid (AA)-activatable $\mathrm{H}^{+}$translocator of neutrophils was investigated. (1) The trifluoromethyl ketone analogue of arachidonate $\left(\mathrm{AACOCF}_{3}\right)$, a newly developed selective blocker of $\mathrm{CPLA}_{2}$, inhibited both the $N$-formylmethionyl-leucylphenylalanine (fMLP)- and the phorbol-ester-induced rheogenic $\mathrm{H}^{+}$efflux $\left(K_{0.5} \approx 5 \mu \mathrm{M}\right)$ and abrogated the stimulus-triggered release of AA from these cells. The drug failed to reduce the fMLP-evoked $\mathrm{Ca}^{2+}$ signal or protein tyrosine phosphorylation and did not affect the activity of protein kinase $\mathrm{C}$. By using the patch-clamp technique we verified that the agent did not interfere with the voltage- and the $\mathrm{pH}$-dependent activation of the $\mathrm{H}^{+}$conductance of the peritoneal macrophages and therefore is not a direct blocker of the $\mathrm{H}^{+}$ channel itself. $\mathrm{AACOCF}_{3}$, however, slightly decreased the AA-
\end{abstract}

induced stimulation of the $\mathrm{H}^{+}$currents. We conclude that AA, liberated by the agonist-induced stimulation of $\mathrm{CPLA}_{2}$, is a direct activator of $\mathrm{H}^{+}$conductance. (2) $\mathrm{AACOCF}_{3}$ did not inhibit superoxide generation, indicating that activation of $\mathrm{cPLA}_{2}$ may not be a prerequisite for turning on NADPH oxidase. (3) Since neither acid generation by the oxidase, nor the basal or stimulated $\mathrm{Na}^{+} / \mathrm{H}^{+}$exchange (the predominant acid-eliminating mechanism) were influenced by the drug, we could use $\mathrm{AACOCF}_{3}$ to address whether the $\mathrm{H}^{+}$channel in fact opens and plays any physiological role during activation of neutrophils. Stimulusinduced cytosolic alkalinization was smaller, whereas depolarization became larger, in the presence of $\mathrm{AACOCF}_{3}$. Stimulated $\mathrm{H}^{+}$conductance therefore does contribute to intracellular $\mathrm{pH}\left(\mathrm{pH}_{\mathrm{i}}\right)$ homoeostasis and membrane potential changes of intact neutrophils.

\section{INTRODUCTION}

The NADPH oxidase of phagocytes is a major weapon in the body's defence against invading micro-organisms. This enzyme catalyses the one-electron reduction of molecular oxygen to superoxide anion, a precursor of bactericidal oxygen radicals. This process is accompanied by a large increase in metabolic acid production [1,2] and, probably due to the transmembrane electron efflux, by a sizeable depolarization [3]. To eliminate deleterious acid, neutrophils are equipped with a set of $\mathrm{H}^{+}$ transporters, including the $\mathrm{Na}^{+} / \mathrm{H}^{+}$exchanger (NHE) [2,4], a vacuolar-type $\mathrm{H}^{+}$-ATPase [5] and a recently described conductive $\mathrm{H}^{+}$pathway $\left(\mathrm{H}^{+}\right.$channel) (as reviewed in $\left.[6,7]\right)$. The basic properties of the last system have been established in studies using fluorimetric determinations of intracellular (cytosolic) $\mathrm{pH}$ $\left(\mathrm{pH}_{\mathrm{i}}\right)$ changes [8-11] and whole-cell voltage clamp measurements [12-15]. The conductance was found to be exquisitely $\mathrm{H}^{+}$-selective voltage-gated outwardly rectifying, regulated by both external and internal protons and sensitive to heavy metals $\left(\mathrm{Cd}^{2+}, \mathrm{Zn}^{2+}\right)$. In spite of the impressive progress in this field, several crucial points remained unresolved. The molecular identity of this transporter is obscure and neither the exact signalling events leading to its activation nor the relative contribution of the channel to the stimulus-induced changes of $\mathrm{pH}_{\mathrm{i}}$ and the membrane potential are currently understood.

Receptor agonists [e.g. ATP, $N$-formylmethionyl-leucylphenylalanine (fMLP), tumour necrosis factor- $\alpha$ ] [15-17] or the direct activation of protein kinase $\mathrm{C}$ (PKC) with phorbol esters (e.g. PMA) [1,10] were reported to increase electrogenic $\mathrm{H}^{+}$ movements in neutrophils. Interestingly, however, the receptormediated activation is insensitive to the PKC inhibitor staurosporine, but it can be blocked by the tyrosine-kinase inhibitor erbstatin, and exactly the opposite is true for the PMA-triggered response [1,10]. These observations imply that both PKCdependent and -independent pathways can signal to the $\mathrm{H}^{+}$ channel. A possible common denominator could be the activation of a phospholipase $\mathrm{A}_{2}\left(\mathrm{PLA}_{2}\right)$ and the consequent liberation of arachidonic acid (AA), which was demonstrated to occur in neutrophils upon stimulation (reviewed in [18]). The assumption that this process might be involved in channel regulation is based on previous findings showing that (1) exogenous arachidonate is a potent stimulator of the conductance [14,19-21] and (2) bromophenacyl bromide, a non-selective broad-spectrum inhibitor of $\mathrm{PLA}_{2}$ enzymes, abolishes both the receptor agonistand the PMA-elicited activation [16,21]. In neutrophils at least two forms of $\mathrm{PLA}_{2}$ have been implicated in AA generation. One

Abbreviations used: AA, arachidonic acid; AACOCF $_{3}$, trifluoromethyl ketone analogue of arachidonic acid; BCECF, 2',7'-bis-(2-carboxyethyl)-5(6)carboxyfluorescein; $\left[\mathrm{Ca}^{2+}\right]_{\mathrm{i}}$, intracellular calcium concentration; $\mathrm{CPLA}_{2}$, cytosolic phospholipase $\mathrm{A}_{2}$; DiSBAC $\mathrm{D}_{2}(3)$, bis-(1,3-diethylthiobarbituric acid)trimethine oxonol; EIPA, ethyl isopropylamiloride; fMLP, $\mathrm{N}$-formylmethionyl-leucylphenylalanine; HPMI, Hepes-buffered RPMI 1640; $\mathrm{NHE}$, Na ${ }^{+} / \mathrm{H}^{+}$ exchanger; NMG, N-methyl-D-glucammonium; $\mathrm{pH}_{\mathrm{i}}$, intracellular $\mathrm{pH}$; $\mathrm{pH}_{\mathrm{o}}$, extracellular $\mathrm{pH}$; PKC, protein kinase $\mathrm{C}$; PLA $\mathrm{A}_{2}$, phospholipase $\mathrm{A}_{2}$; $\mathrm{PLC}$, phospholipase $\mathrm{C}$; sPLA, secretory phospholipase $\mathrm{A}_{2}$.

* To whom correspondence should be addressed. 
of them is a $14 \mathrm{kDa}$ secretory-type enzyme $\left(\mathrm{sPLA}_{2}\right)$ that requires high (probably millimolar) calcium concentrations for the catalysis [22-24]. The other one is a cytosolic PLA (cPLA $\left._{2}\right)$, with an apparent molecular mass of $85 \mathrm{kDa}$ [25-27]. This enzyme is specific for AA in the $s n-2$ position of phospholipids and requires submicromolar $\mathrm{Ca}^{2+}$ concentrations for translocation to membranes [28-31]. The relative contribution (if any) of these enzymes to the control of different effector functions of neutrophils (e.g. superoxide production, $\mathrm{H}^{+}$-channel activation) has not been clarified.

The first aim of the present study was to assess whether $\mathrm{CPLA}_{2}$ is involved in the regulation of the $\mathrm{H}^{+}$conductance. This problem was approached by using a newly developed selective inhibitor of this enzyme, the trifluoromethyl ketone analogue of arachidonate $\left(\mathrm{AACOCF}_{3}\right)$ [32-34]. We found this drug to be a specific antagonist of $\mathrm{H}^{+}$-channel activation, which did not interfere with other $\mathrm{H}^{+}$-generating or $\mathrm{H}^{+}$-eliminating processes. Having obtained this result we could use $\mathrm{AACOCF}_{3}$ to address another long-debated issue regarding the physiology of the $\mathrm{H}^{+}$conductance. The rheogenic $\mathrm{H}^{+}$transport of phagocytes has previously been studied under rather extreme conditions (in acidified and depolarized cells, by using charge compensation and excluding the participation of other $\mathrm{H}^{+}$transporters). During activation in a physiological environment, intact cells do undergo depolarization, produce acid and secrete arachidonate. Each of these events would of course favour the operation of the $\mathrm{H}^{+}$ pathway. However, it remained questionable whether the extent of these changes is sufficient to provide an outward $\mathrm{H}^{+}$gradient and whether it is sufficient to open up the conductance.

Our results suggest that $\mathrm{CPLA}_{2}$ plays an important role in the regulation of the $\mathrm{H}^{+}$channel, and this transporter does participate in $\mathrm{pH}_{\mathrm{i}}$ homoeostasis and membrane-potential changes of neutrophils stimulated in a physiological environment.

\section{EXPERIMENTAL}

\section{Reagents and solutions}

$\mathrm{AACOCF}_{3}$ (kept under nitrogen as a $15 \mathrm{mM}$ stock solution in ethanol), 2',7'-bis-(2-carboxyethyl)-5(6)-carboxyfluorescein (BCECF) acetoxymethyl ester and nigericin were from Calbiochem, and bis-(1,3-diethylthiobarbituric acid)trimethine oxonol [DiSBAC ${ }_{2}(3)$ ] was obtained from Molecular Probes. DMSO, PMA, AA, fMLP, Hepes, Mes, Pipes, $N$-methyl-Dglucammonium (NMG) and aspartic acid were purchased from Sigma. Valinomycin was from Serva, Percoll from Pharmacia and powdered Brewer's thioglycollate from Difco. Tritiated AA $\left(\left[5,6,8,9,11,12,14,15-{ }^{3} \mathrm{H}\right] \mathrm{AA}\right)$ with a specific radioactivity of $7 \mathrm{TBq} / \mathrm{mmol}(189.1 \mathrm{Ci} / \mathrm{mmol})$ was obtained from Izotóp Intézet (Budapest, Hungary). Bafilomycin $\mathrm{A}_{1}$ was obtained from Dr. K. Altendorf (University of Osnabrück, Germany), and diphenylene iodonium and ethyl isopropylamiloride (EIPA) were kindly given by Dr. A. Nanda (Hospital for Sick Children, Toronto, Canada) and Dr. J. E. Cragoe, Jr. (Merck Sharp \& Dohme, Rahway, NJ, U.S.A.) respectively. All other reagents were of analytical grade.

The $\mathrm{K}^{+}$medium contained $140 \mathrm{mM} \mathrm{KCl}, 10 \mathrm{mM}$ Hepes and $5 \mathrm{mM}$ glucose, $\mathrm{pH}$ 7.5. The $\mathrm{Na}^{+}$medium consisted of $140 \mathrm{mM}$ $\mathrm{NaCl}, 5 \mathrm{mM} \mathrm{KCl}, 0.8 \mathrm{mM} \mathrm{CaCl}, 1 \mathrm{mM} \mathrm{MgCl}{ }_{2}, 10 \mathrm{mM}$ Hepes and $5 \mathrm{mM}$ glucose, $\mathrm{pH}$ 7.4. The choline medium contained $140 \mathrm{mM}$ choline chloride, $10 \mathrm{mM}$ Hepes and $5 \mathrm{mM}$ glucose, $\mathrm{pH}$ 7.4. The composition of media used for the patch-clamp studies are detailed below. NMG-Asp 6.0:100 mM Mes, $123 \mathrm{mM}$ NMG, $77 \mathrm{mM}$ aspartic acid, pH 6.0. NMG-Asp 6.8: $100 \mathrm{mM}$ Pipes, $175 \mathrm{mM}$ NMG, $25 \mathrm{mM}$ aspartic acid, $\mathrm{pH}$ 6.8. NMG-Asp 7.5: $100 \mathrm{mM}$ Hepes, $125 \mathrm{mM} \mathrm{NMG}, 75 \mathrm{mM}$ aspartic acid,
$\mathrm{pH}$ 7.5. $\mathrm{KCl}$ 6.8: $100 \mathrm{mM}$ Pipes, $75 \mathrm{mM} \quad \mathrm{KCl}, 50 \mathrm{mM}$ $\mathrm{KOH}, \mathrm{pH} 6.8 . \mathrm{KCl}$ 7.5: $100 \mathrm{mM}$ Hepes, $75 \mathrm{mM} \mathrm{KCl}$, $50 \mathrm{mM} \mathrm{KOH}, \mathrm{pH}$ 7.5. All of these solutions were supplemented with $1 \mathrm{mM}$ EGTA and $1 \mathrm{mM} \mathrm{MgCl}_{2}$.

\section{Isolation of human neutrophil granulocytes and peripheral lymphocytes}

Citrated venous blood was obtained from healthy volunteers. Leukocytes were isolated by dextran sedimentation followed by $55 \%(\mathrm{v} / \mathrm{v})$ Percoll-gradient centrifugation as described in refs. $[35,36]$. Granulocytes were collected from the bottom layer and lymphocytes from the top. Contaminating erythrocytes were removed by hypotonic lysis. The isolated granulocytes and lymphocytes were suspended in Hepes-buffered RPMI 1640 (HPMI) or PBS medium respectively and stored at room temperature until use. The purity of both the neutrophil and the lymphocyte preparations was $>95 \%$, as determined by Giemsa staining.

\section{Elicitation and plating of mouse peritoneal macrophages}

Peritoneal macrophages were obtained from FLCP mice that were injected intraperitoneally with $2 \mathrm{ml}$ of thioglycollate 5 days before harvest, as described in refs. [13,20]. The peritoneal cavity was rinsed with $10 \mathrm{ml}$ of Hanks balanced salt solution and exudate cells were sedimented with centrifugation at $900 \mathrm{~g}$ for $10 \mathrm{~min}$. The latter procedure was repeated twice, then cells were resuspended in sterile HPMI (approx. $4 \times 10^{6} / \mathrm{ml}$ ), placed in Eppendorf tubes and rotated end-over-end until use. Macrophages (approx. $2 \times 10^{5}$ ) were plated on glass coverslips, which formed the bottom of a Leiden dish containing $0.7 \mathrm{ml}$ HPMI. Cells were allowed to adhere for 5-10 min, after which the chamber was washed 3 times with HPMI to remove the few $(<10 \%)$ contaminating non-adherent cells (mostly lymphocytes). During the patch-clamp measurements the chamber was continuously perfused with the selected bath media using a gravity-driven system and a Leiden aspirator. The flow rate was approx. $0.5 \mathrm{ml} / \mathrm{min}$, providing a complete exchange of the bath solution once in every $90 \mathrm{~s}$.

\section{Measurement of $\mathrm{pH}_{\mathrm{i}}$}

$\mathrm{pH}_{\mathrm{i}}$ was determined fluorimetrically using the $\mathrm{pH}$-sensitive dye 2',7'-bis-(2-carboxyethyl)-5(6)-carboxyfluorescein as described [10]. Briefly, separate batches of cells $\left(2 \times 10^{6}\right)$ were loaded with $2 \mu \mathrm{M}$ BCECF acetoxymethyl ester for $10 \mathrm{~min}$ at $37^{\circ} \mathrm{C}$. Dye-loaded cells were sedimented, washed and resuspended in $2.5 \mathrm{ml}$ of $\mathrm{K}^{+}$or $\mathrm{Na}^{+}$medium. Fluorescence of the cell suspension was monitored in a stirred, thermostatically controlled cuvette using a Perkin-Elmer 3000 spectrofluorimeter. Emission and excitation wavelengths were $495 \mathrm{~nm}$ (5 nm slit) and $540 \mathrm{~nm}$ ( $5 \mathrm{~nm}$ slit) respectively. To exclude potential optical artifacts due to changes in cell shape or size, experiments were occasionally repeated or performed using a Deltascan dualwavelength spectrofluorimeter (Photon Technology International, South Brunswick, NJ, U.S.A.) operating in the dualexcitation $(440 / 490 \mathrm{~nm})$ single-emission $(530 \mathrm{~nm})$ mode. The results obtained with conventional fluorimetry and with ratio fluorimetry were identical. Calibration of fluorescence intensity versus $\mathrm{pH}_{\mathrm{i}}$ was performed in the presence of nigericin (for $\mathrm{K}^{+}$ medium) or in the presence of nigericin and monensin (for $\mathrm{Na}^{+}$medium). Because the cytosolic $\mathrm{H}^{+}$-buffering capacity is relatively constant in the $\mathrm{pH}_{\mathrm{i}}$ range studied [4], transmembrane $\mathrm{H}^{+}$-(equivalent) fluxes result in proportional changes in $\mathrm{pH}_{\mathrm{i}}$. 


\section{Determination of AA release}

Isolated granulocytes $\left(10^{7} / \mathrm{ml}\right)$ were preincubated in HPMI in the presence of tritiated arachidonate $(1 \mu \mathrm{Ci} / \mathrm{ml})$ for $30 \mathrm{~min}$ at $37^{\circ} \mathrm{C}$. Subsequently, cells were washed three times with $\mathrm{Na}^{+}$ medium supplemented with $0.1 \%(\mathrm{v} / \mathrm{v})$ fatty-acid-free BSA and resuspended in the same solution at $10^{7}$ cells $/ \mathrm{ml}$. With this labelling procedure approx. $60 \%$ of the total radioactivity was incorporated into the cells. For determination of AA release, $100 \mu 1$ aliquots of the labelled cells were added to $300 \mu 1$ of $\mathrm{Na}^{+}$ medium supplemented with $0.1 \%$ BSA and with the appropriate (final) concentration of $\mathrm{AACOCF}_{3}$. After $10 \mathrm{~min}$ at $37^{\circ} \mathrm{C}$, cells were either left untreated or stimulated with $25 \mathrm{nM}$ PMA or $2 \mu \mathrm{M}$ fMLP for $10 \mathrm{~min}$. At the end of this period cells were rapidly sedimented and the radioactivity of the supernatant was measured in a Beckman 5000 LS liquid-scintillation system.

\section{Measurement of intracellular $\mathrm{Ca}^{2+}$ concentration $\left(\left[\mathrm{Ca}^{2+}\right]_{\mathrm{i}}\right)$}

$\left[\mathrm{Ca}^{2+}\right]_{\mathrm{i}}$ was measured with ratio fluorimetry using fura 2 as detailed in [35]. Briefly, $5 \times 10^{7}$ cells were loaded with $4 \mu \mathrm{M}$ of fura 2 acetoxymethyl ester for $30 \mathrm{~min}$ at $37^{\circ} \mathrm{C}$. After washing, dye-loaded cells $\left(3 \times 10^{6}\right)$ were suspended in $3 \mathrm{ml}$ of $\mathrm{Na}^{+}$medium and incubated with or without $\mathrm{AACOCF}_{3}$ for $5 \mathrm{~min}$ before stimulation with $1 \mu \mathrm{M}$ fMLP. Fluorescence was recorded with the Deltascan dual-wavelength spectrofluorimeter using wavelengths $340 / 380 \mathrm{~nm}$ for excitation and $505 \mathrm{~nm}$ for emission. Data were analysed with the Felix software (PTI).

\section{Detection of protein tyrosine phosphorylation}

To determine tyrosine phosphorylation of proteins, neutrophils $\left(10^{7} / \mathrm{ml}\right)$ were preincubated with or without $\mathrm{AACOCF}_{3}$, followed by stimulation with $1 \mu \mathrm{M}$ fMLP similarly to that described in [37]. After 0.5 or $1 \mathrm{~min}$ the reaction was stopped by placing the samples on ice, and the cells were immediately sedimented by rapid spinning. The pellet was resuspended in hot sample buffer containing $2 \%(\mathrm{w} / \mathrm{v})$ SDS and boiled for $10 \mathrm{~min}$. Samples $\left(10^{6}\right.$ cell-equivalents per lane) were subjected to electrophoresis on $10 \%(\mathrm{w} / \mathrm{v})$ polyacrylamide gels (SDS/PAGE) and the proteins were transferred to nitrocellulose. The membranes were blocked with $2 \%$ BSA in Tris buffered saline, incubated with monoclonal anti-phosphotyrosine (UBI clone 4G10) antibodies, extensively washed and incubated with peroxidase-conjugated goat antimouse IgG (Amersham). After several washings the Western blots were developed by the enhanced chemiluminescence system (Amersham).

\section{PKC activity measurements}

PMA-induced PKC activity in sonicated human neutrophil and lymphocyte lysates was determined by using a selective oligopeptide substrate of PKC (Ala-Ala-Ala-Ser-Phe-Lys-Ala-LysLys-amide) essentially as described in [38]. Radioactive phosphate, incorporated in the presence or absence of $\mathrm{AACOCF}_{3}$, into the oligopeptide was determined as in [38].

\section{Patch-clamp measurements}

The whole-cell configuration of the patch-clamp technique was used to record ionic currents in macrophages essentially as described in refs. $[13,20]$. Patch-clamp electrodes were pulled from borosilicate glass capillaries (outside diameter $1.5 \mathrm{~mm}$; World Precision Instruments) using a P-87 horizontal puller (Sutter Instruments Co.) and were fire polished with an LSR microforge (Intracel). The resulting pipettes had resistances of between 2 and $6 \mathrm{M} \Omega$. Before data collection, cell capacitance (11-27 pF) was compensated with the built-in circuitry of the amplifier. Currents were recorded using a Bio-Logic RK-400 amplifier in the voltage clamp mode coupled to a HKC 409 headstage. Whole-cell currents were filtered at $3 \mathrm{kHz}$ and digitally sampled using a Digidata 1200 interface board (Axon Instruments). Leak current was determined by stepping the voltage from the holding potential of $-60 \mathrm{mV}$ to $-90 \mathrm{mV}$ in $15 \mathrm{mV}$ steps. Where necessary, linear leak was subtracted from the traces. Currents were normalized to cell capacitance.

\section{Determination of superoxide production}

NADPH oxidase activity was followed as the superoxidedismutase-inhibitable reduction of ferricytochrome $c$. Cells $\left(10^{6} / \mathrm{ml}\right)$ were suspended in $\mathrm{Na}^{+}$medium containing $100 \mu \mathrm{M}$ ferricytochrome $c$ and, where indicated, $0.1 \%$ BSA. After a 10 min incubation with or without the indicated concentration of $\mathrm{AACOCF}_{3}$ at $37^{\circ} \mathrm{C}$, the cell suspension was placed on 96 -well microplates and the reaction was started by adding the appropriate stimuli. Changes in absorption were followed at $550 \mathrm{~nm}$ using a Labsystems iEMS Microplate Reader. Absorption of the unstimulated samples was subtracted and absorbance was converted into $\mathrm{O}_{2}^{-}$production using an absorption coefficient of $21.1 \mathrm{mM}^{-1} \cdot \mathrm{cm}^{-1}$. Measurements were performed in the absence of cytochalasin $\mathrm{B}$.

\section{Membrane potential measurements}

Membrane potential was followed fluorimetrically using DiSBAC $_{2}(3)$. Cells $\left(2 \times 10^{6}\right)$ were suspended in $\mathrm{Na}^{+}$medium supplemented with $200 \mathrm{nM} \mathrm{DiSBAC}{ }_{2}(3)$. After equilibrium has been reached the cells were further incubated in the presence or absence of $15 \mu \mathrm{M} \mathrm{AACOCF}$ for 5 min and then were stimulated with $20 \mathrm{nM}$ fMLP. The excitation and emission wavelengths were $535 \mathrm{~nm}$ and $559 \mathrm{~nm}$ respectively. No change in the baseline fluorescence was detected in the presence of $\mathrm{AACOCF}_{3}$ and complete depolarization of the cells by gramicidin caused a similar increase in fluorescence in the presence or absence of the inhibitor. Qualitatively identical results were obtained by using 3,3'-dipentyloxacarbocyanine iodide [3], although $\mathrm{AACOCF}_{3}$ caused an increase in the fluorescence of this dye.

\section{Statistical analysis}

Data are presented either as representative traces of at least three experiments performed on cells of different donors, or as the means \pm S.E.M. of the number of determinations indicated $(n)$.

\section{RESULTS}

\section{$\mathrm{AACOCF}_{3}$ blocks fMLP- and PMA-induced electrogenic $\mathrm{H}^{+}$ translocation}

To assess the potential role of $\mathrm{CPLA}_{2}$ in the regulation of the rheogenic $\mathrm{H}^{+}$transporter of neutrophils, we tested the effect of $\mathrm{AACOCF}_{3}$, a newly described specific blocker of this enzyme, on the conductive $\mathrm{H}^{+}$fluxes induced by various stimulants. $\mathrm{H}^{+}$ movements were followed by recording changes in $\mathrm{pH}_{\mathrm{i}}$ under conditions where the contribution of other $\mathrm{H}^{+}$-translocating systems and major acidifying mechanisms were shown to be eliminated [1,10]. Briefly, $\mathrm{pH}_{\mathrm{i}}$ was monitored in a $\mathrm{KCl}$-based $\mathrm{Na}^{+}$- and $\mathrm{HCO}_{3}{ }^{-}$-free medium, thus excluding the involvement of $\mathrm{Na}^{+} / \mathrm{H}^{+}$and $\mathrm{Cl}^{-} / \mathrm{HCO}_{3}{ }^{-}$antiporters. Bafilomycin was applied to inhibit the vacuolar-type $\mathrm{H}^{+}$-ATPase, and $\mathrm{H}^{+}$generation by NADPH oxidase was blocked by diphenyleneiodonium. 
(a)

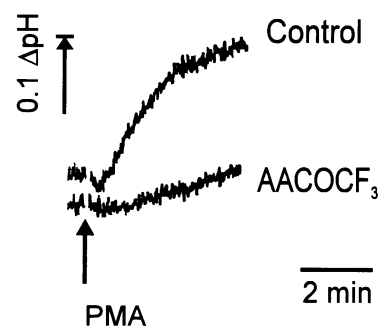

(c)

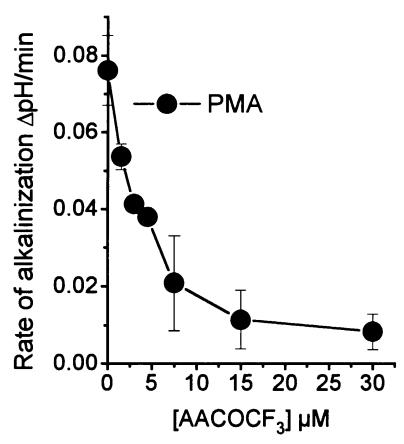

(b)

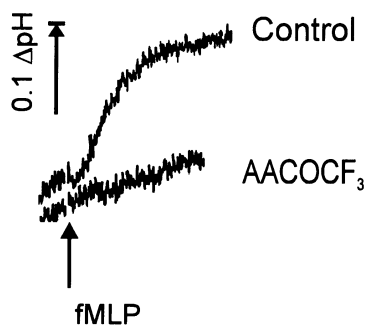

(d)

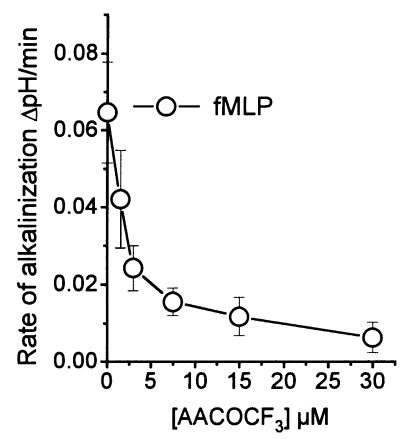

Figure 1 Effect of $\mathrm{AACOCF}_{3}$ on the PMA- and fMLP-induced activation of the electrogenic $\mathrm{H}^{+}$conductance of neutrophils

BCECF-loaded neutrophils $\left(2 \times 10^{6}\right)$ were suspended in $2.5 \mathrm{ml}$ of $\mathrm{KCl}$ medium supplemented with $100 \mathrm{nM}$ bafilomycin $\mathrm{A}_{1}, 0.8 \mu \mathrm{M}$ valinomycin and $4 \mu \mathrm{M}$ diphenyleneiodonium. The initial $\mathrm{pH}_{\mathrm{i}}$ was approx. 7.0. Cells were either left untreated (control) or were preincubated with $30 \mu \mathrm{M}$ $\mathrm{AACOCF}_{3}$ for $5 \mathrm{~min}$, and then stimulated with $10 \mathrm{nM}$ PMA (a) or $1 \mu \mathrm{M} \mathrm{fMLP}(\mathbf{b})$ as indicated by the arrows. For both stimuli one pair of fluorimetric traces, representative of five similar experiments, is shown. For the sake of clarity traces were shifted vertically. Initial rates of $\mathrm{pH}_{\mathrm{i}}$ increase induced by PMA (c) or $\mathrm{AMLP}$ (d) were determined in the presence of various $\mathrm{AACOCF}_{3}$ concentrations $\left[\mathrm{AACOCF}_{3}\right]$. Data are means \pm S.E.M. of three separate experiments.

Formation of a diffusion potential that might limit the free permeation of protons through the conductance was prevented by the addition of the $\mathrm{K}^{+}$ionophore, valinomycin. Under these conditions [extracellular $\mathrm{pH}\left(\mathrm{pH}_{\mathrm{o}}\right) 7.5$ ] the steady-state $\mathrm{pH}_{\mathrm{i}}$ of the cells was $7.06 \pm 0.032(n=12)$. Addition of PMA $(10 \mathrm{nM})$ or fMLP $(1 \mu \mathrm{M})$ triggered a substantial cytoplasmic alkalinization, with initial rates of $0.076 \pm 0.013 \Delta \mathrm{pH} / \mathrm{min} \quad(n=5)$ and $0.068 \pm 0.009 \Delta \mathrm{pH} / \mathrm{min}(n=5)$ respectively (Figures $1 \mathrm{a}$ and $1 \mathrm{~b})$. No alkalinization was observed in the presence of $\mathrm{Zn}^{2+}$ or $\mathrm{Cd}^{2+}$, further confirming that the $\mathrm{H}^{+}$movements took place through heavy-metal-sensitive $\mathrm{H}^{+}$conductance (results not shown). Preincubation of the cells with $\mathrm{AACOCF}_{3}$ inhibited both the PMAand the $\mathrm{fMLP}$-induced rise in $\mathrm{pH}_{\mathrm{i}}$ in a concentration-dependent manner (Figures 1c and 1d). In the case of both stimuli, 50\% inhibition was attained at 3-5 $\mu \mathrm{MAACOCF}$. This concentration range corresponds to the $K_{0.5}$ values reported for the inhibition of CPLA $_{2}$ in other cell types [33,34].

\section{Effect of $\mathrm{AACOCF}_{3}$ on signal-transducing elements involved in the regulation of the $\mathrm{H}^{+}$translocator}

To decide whether the strong inhibition of $\mathrm{H}^{+}$fluxes by AACOCF ${ }_{3}$ could be attributed to an inhibitory effect of the drug on $\mathrm{cPLA}_{2}$, we tried to clarify two essential points. First we

Table $1 \mathrm{AACOCF}_{3}$ inhibits PMA- and fMLP-promoted arachidonic acid release from neutrophils

Cells $\left(10^{6}\right)$, labelled with $\left.{ }^{3} \mathrm{H}\right]$ arachidonate, as described in the Experimental section, were suspended in $400 \mu \mathrm{l}$ of $\mathrm{Na}^{+}$medium containing $0.1 \% \mathrm{BSA}$ and preincubated in the absence or in the presence of varying concentrations of $\mathrm{AACOCF}_{3}\left(\left[\mathrm{AACOCF}_{3}\right]\right)$ for 10 min at $37^{\circ} \mathrm{C}$. After this period cells were either left untreated (basal) or stimulated with PMA (25 nM) or fMLP $(2 \mu \mathrm{M})$ for an additional $10 \mathrm{~min}$. Thereafter neutrophils were rapidly sedimented and the radioactivity of the supernatant was determined. Data are means \pm S.E.M. of triplicates from one representative experiment. Statistics of eight similar, independent experiments are given in the text.

\begin{tabular}{llll}
\hline & \multicolumn{3}{l}{$\left[{ }^{3} \mathrm{H}\right]$ Arachidonate release (c.p.m.) } \\
\cline { 2 - 4 }$\left[\mathrm{AACOCF}_{3}\right](\mu \mathrm{M})$ & Basal & PMA & fMLP \\
\hline- & & & \\
\hline 15 & $1302 \pm 31$ & $1808 \pm 79$ & $1762 \pm 10$ \\
30 & $1382 \pm 86$ & $1762 \pm 41$ & $1667 \pm 54$ \\
60 & $1469 \pm 4$ & $1525 \pm 50$ & $1513 \pm 31$ \\
& $1225 \pm 25$ & $1293 \pm 0$ & $1175 \pm 59$ \\
\hline
\end{tabular}

investigated whether AA generation elicited by the applied stimuli could indeed be abrogated by $\mathrm{AACOCF}_{3}$. Second, we tested whether the drug could influence other signalling pathways that are suspected to be involved in the regulation of the $\mathrm{H}^{+}$ conductance.

AA liberation upon cell stimulation was determined by measuring the release of radioactivity into the external medium from $\left[{ }^{3} \mathrm{H}\right] \mathrm{AA}$-labelled cells. The amount of released AA (and its metabolites) measured with this technique was reported to be in good correlation with the total AA generated in the membrane $[39,40]$. Incubation of the cells for $10 \mathrm{~min}$ in the presence of PMA or fMLP increased the release of AA by $30.96 \pm 2.72 \%$ and $26.44 \pm 3.9 \%$ respectively compared with the unstimulated controls ( $n=8$, each performed in triplicate). Although modest, these increases were very consistent and significant $(P<0.001)$, and the values are close to the data obtained by other investigators under comparable conditions (no cytochalasin present) [26,39]. Table 1 shows that $\mathrm{AACOCF}_{3}$ added alone, at concentrations between 15 and $60 \mu \mathrm{M}$, either had no influence or caused a slight increase in the release of AA. Importantly, the drug inhibited the liberation of AA induced by PMA or fMLP, and this effect was concentration-dependent and complete at $60 \mu \mathrm{M}$. Comparing Figure 1 and Table 1, however, reveals that somewhat higher concentrations were required to suppress AA release than to block $\mathrm{H}^{+}$translocation. This difference could be due to the different compositions of the media used for the two assays. The medium applied for the determination of AA release contained $0.1 \%$ BSA to trap the fatty acid. Albumin, however, is likely to bind $\mathrm{AACOCF}_{3}$ as well, lowering its effective concentration. Indeed we found that in the presence of $0.1 \%$ BSA comparably higher concentrations of $\mathrm{AACOCF}_{3}$ were required to reduce $\mathrm{H}^{+}$ fluxes (results not shown). The above results indicate that $\mathrm{AACOCF}_{3}$ is capable of preventing both the receptor-mediated and the PKC-dependent stimulation of AA release.

A major complication in interpreting previous data obtained with other PLA $\mathrm{A}_{2}$ inhibitors (bromophenacyl bromide, scalaradial, etc.) was that these drugs, in addition to blocking all forms of $\mathrm{PLA}_{2}$, interfered also with other signal-transducing proteins, such as phospholipase $\mathrm{C}$ (PLC) and PKC [21,22]. To provide a reliable pharmacological basis for the interpretation of our results, we tested the action of $\mathrm{AACOCF}_{3}$ on other signalling events that were proposed to be involved in the regulation of the $\mathrm{H}^{+}$channel [15-17,21]. First we investigated the fMLP-induced 
(a)

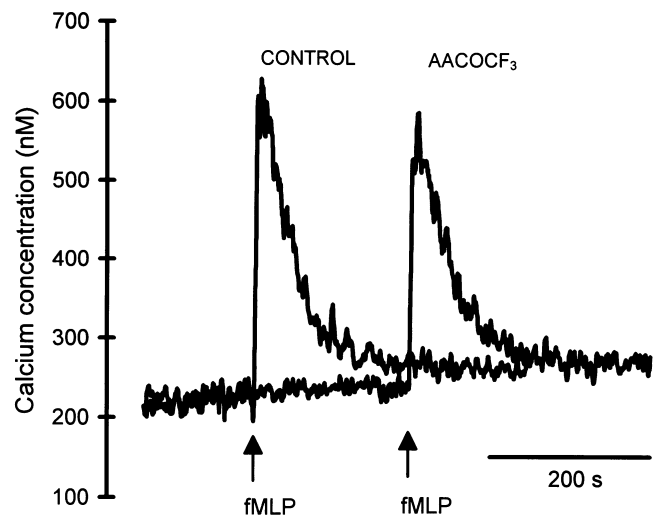

(b)

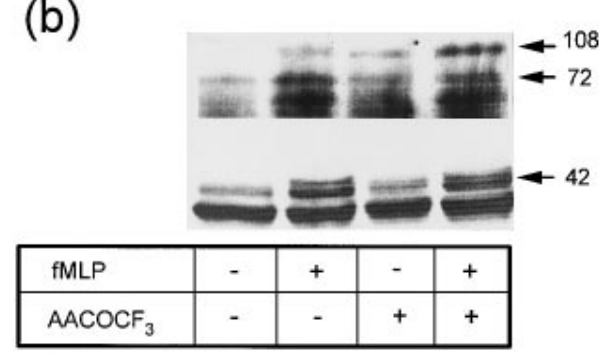

Figure $2 \mathrm{AACOCF}_{3}$ does not alter the $\mathrm{fMLP}$-induced $\mathrm{Ca}^{2+}$ signal (a) and protein tyrosine phosphorylation (b)

(a) Fura 2-loaded neutrophils $\left(10^{6} / \mathrm{ml}\right)$ were suspended in $\mathrm{Na}^{+}$medium, incubated for $5 \mathrm{~min}$ in the absence (control) or presence of $15 \mu \mathrm{M} \mathrm{AACOCF}_{3}$ and stimulated with $1 \mu \mathrm{M} \mathrm{fMLP}$ (as shown by the arrows). Changes in $\left[\mathrm{Ca}^{2+}\right]_{\mathrm{i}}$ were monitored using ratio fluorimetry as detailed in the Experimental section. Traces were shifted horizontally for the sake of better presentation. (b) For determination of protein tyrosine phosphorylation, neutrophils were preincubated for $10 \mathrm{~min}$ in the presence or absence of $15 \mu \mathrm{M} \mathrm{AACOCF}$ as indicated. The cells were then either left untreated or challenged with $1 \mu \mathrm{M}$ fMLP (as indicated). Since the kinetics of phosphotyrosine accumulation are different in various proteins, the phosphorylation of the 108 and $72 \mathrm{kDa}$ protein was best detected after $0.5 \mathrm{~min}$ stimulation (upper part), whereas the change in the $42 \mathrm{kDa}$ band was best visualized after 1 min treatment with fMLP (lower part). The upper and lower blots are spliced together from two different experiments. Proteins of whole-cell lysates were analysed by a Western blot technique using anti-phosphotyrosine antibody and the enhanced chemiluminescence method, as detailed in the Experimental section. The arrows indicate the 108,72 and $42 \mathrm{kDa}$ proteins.

calcium signal in the absence and presence of the drug. As shown in Figure 2(a), neither the amplitude nor the kinetics of the $\left[\mathrm{Ca}^{2+}\right]_{\mathrm{i}}$ response was altered by $\mathrm{AACOCF}_{3}$. This finding suggests that both the ligand binding by the receptor and the subsequent activation of PLC remained intact. Next we looked at whether PKC, another well-known regulator of the channel, could preserve its normal activity in the presence of $\mathrm{AACOCF}_{3}$. To this end we determined the PMA-induced phosphorylation of a PKC-specific peptide substrate by cell lysates incubated with or without the drug. $\mathrm{AACOCF}_{3}$ failed to influence PKC activity even at concentrations as high as $150 \mu \mathrm{M}$ (results not shown). Finally we checked the effect of the compound on the fMLPinduced protein tyrosine phoshorylation, a process that was also shown to play an important role in the activation of $\mathrm{H}^{+}$transport [8]. In agreement with previous reports, fMLP increased phosphotyrosine accumulation generally in three protein bands with apparent molecular masses of 42, 72 and $108 \mathrm{kDa}[37,41]$. As shown in Figure 2(b), the fMLP-induced tyrosine phosphorylation was not prevented by $\mathrm{AACOCF}_{3}$.
Taken together, the action of $\mathrm{AACOCF}_{3}$ seems to be specific for $\mathrm{CPLA}_{2}$ and the observed inhibition of $\mathrm{AA}$ release is probably not due to interference with events upstream of $\mathrm{cPLA}_{2}$.

\section{Effect of $\mathrm{AACOCF}_{3}$ on voltage-dependent $\mathrm{H}^{+}$currents}

To test whether $\mathrm{AACOCF}_{3}$ could directly influence the $\mathrm{H}^{+}$ conductance itself, we investigated the effect of the drug on the voltage-dependent $\mathrm{H}^{+}$currents. These electrophysiological studies were performed on peritoneal macrophages, since $\mathrm{H}^{+}$ currents in these cells are well characterized $[13,20]$ and qualitatively similar to those reported in neutrophils $[12,14,15]$, but macrophages are much easier to patch. An additional advantage of macrophages over neutrophils is that they do not get completely activated simply by adhering to the coverslip, and therefore basal currents can also be obtained. To exclude the potential participation of currents not carried by protons, in our initial measurements we applied NMG-aspartate-based media for both the pipette and the bath solutions, as these large ions are impermeant through most channels present in macrophages [13]. To promote $\mathrm{H}^{+}$fluxes and to minimize internal $\mathrm{pH}$ changes, a substantial $\mathrm{pH}$ gradient was established $\left(\mathrm{pH}_{\mathrm{i}} 6.0 / \mathrm{pH}_{\mathrm{o}} 7.5\right)$ and high buffer concentrations were used (see the Experimental section). At the holding potential of $-60 \mathrm{mV}$ no current was flowing across the cell membrane. To obtain a current-voltage relationship ( $I-V$ curve), 3 s-long voltage pulses were applied between -90 and $+75 \mathrm{mV}$ in $15 \mathrm{mV}$ increments. As shown in Figure 3(a), no current was detected at hyperpolarizing potentials, whereas sizeable outward currents appeared and progressively increased at voltages above $-45 \mathrm{mV}$. These currents showed all the previously reported characteristics of $\mathrm{H}^{+}$currents: they were slowly activating (steady state was reached at $>2 \mathrm{~s}$ ), and strictly outwardly rectifying and sensitive to $\mathrm{Zn}^{2+}$ (not shown). Most importantly, the reversal potential for these currents changed with the $\mathrm{pH}$ gradient: at $\mathrm{pH}_{\mathrm{i}} 6 / \mathrm{pH}_{\mathrm{o}} 7.5$ it was approx. $-80 \mathrm{mV}$, whereas at $\mathrm{pH}_{\mathrm{i}} 6.8 / \mathrm{pH}_{\mathrm{o}} 7.5$ it decreased to $-40 \mathrm{mV}$. These values are very close to the predicted equilibrium potentials for protons $(-90 \mathrm{mV}$ and $-42 \mathrm{mV}$ respectively), confirming that the conductance was exquisitely $\mathrm{H}^{+}$selective. After establishing the control $I-V$ curve, we perfused each cell for 8-10 min with the bath solution supplemented with $15 \mu \mathrm{M}$ $\mathrm{AACOCF}_{3}$ and repeated the voltage protocol. Figure 3(a) shows that the $I-V$ relationship remained essentially the same. The drug caused only a marginal $(<10 \%$ at $60 \mathrm{mV})$ and statistically non-significant decrease in the amplitude of the current and did not change its voltage dependence. (It is worth noting that even this minimal decrease was probably due to a small time-dependent run-down rather than to $\mathrm{AACOCF}_{3}$, since it was often observed also when perfusion was continued for $10 \mathrm{~min}$ without the drug.) These findings, together with the observation that the AA analogue did not affect the basal values, i.e. the valinomycininduced $\mathrm{pH}_{\mathrm{i}}$ changes in neutrophils, give credence to the conclusion that $\mathrm{AACOCF}_{3}$ is not a direct blocker of the voltagedependent $\mathrm{H}^{+}$conductance.

We and others have shown that AA is a potent stimulator of the rheogenic $\mathrm{H}^{+}$pathway [14,19-21] that is presumably acting directly on the putative channel. It was therefore conceivable that $\mathrm{AACOCF}_{3}$ (an AA analogue) might interfere with the arachidonate-induced activation of the translocator. We addressed this possibility by comparing the effect of arachidonate on the voltage-induced $\mathrm{H}^{+}$currents in the absence and presence of $\mathrm{AACOCF}_{3}$. For these experiments we used bilateral $\mathrm{KCl}$ solutions and a smaller $\mathrm{pH}$ gradient $\left(\mathrm{pH}_{\mathrm{i}} 6.8 / \mathrm{pH}_{\mathrm{o}} 7.5\right)$, conditions that were very similar to those applied during the fluorimetric determinations. For better comparability of data obtained on the 
(a)

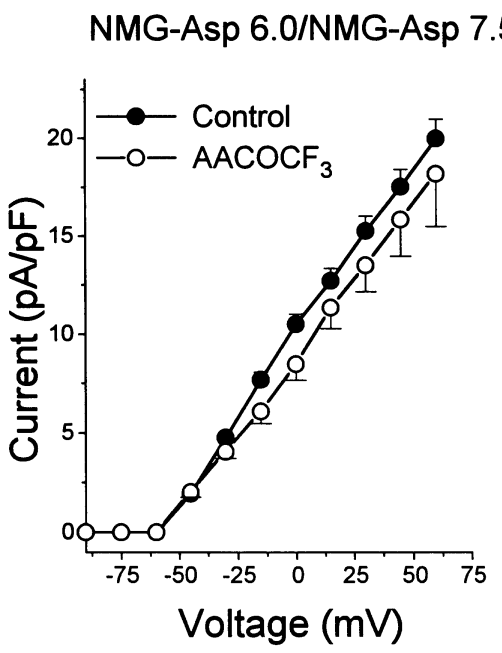

(b)

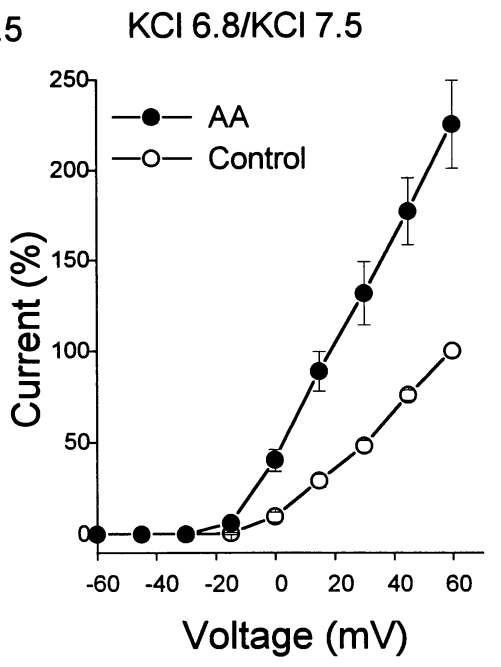

(c)

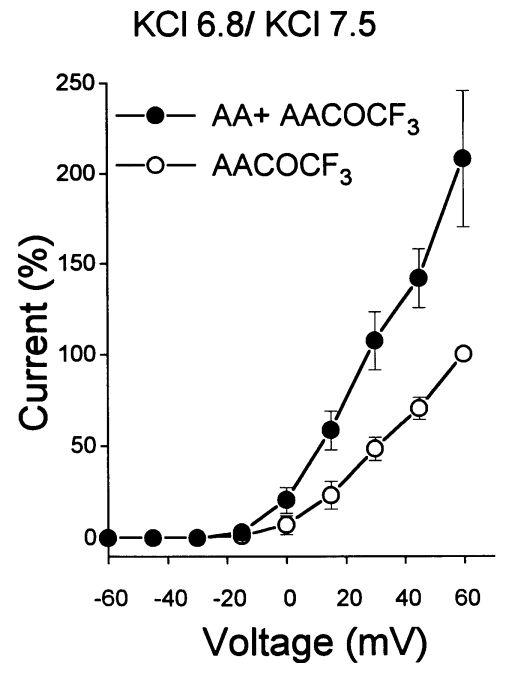

Figure 3 Effect of $\mathrm{AACOCF}_{3}$ on the basal and the AA-stimulated $\mathrm{H}^{+}$currents of macrophages

Adherent macrophages were voltage-clamped in the whole-cell configuration at a holding potential of $-60 \mathrm{mV}$. (a) The pipette contained NMG-Asp, pH 6.0, while the bath was perfused with NMGAsp, pH 7.5. After 8-10 min, a control current-voltage relationship was obtained using $3 \mathrm{~s}$ voltage pulses between -90 and $+60 \mathrm{mV}$ in $15 \mathrm{mV}$ increments and separated by $30 \mathrm{~s}$ intervals (O). The bath was then supplemented with $15 \mu \mathrm{M} \mathrm{AACOCF}$, the same cell was perfused for a further 8-10 min and the voltage protocol was repeated ( $\bigcirc$ ). Currents obtained at the end of each individual voltage pulse were normalized to cell capacitance and plotted against the applied voltage. For (b) and (c) the pipette solution was $\mathrm{KCl}$, pH 6.8, while the bath was $\mathrm{KCl}$, pH 7.5. (b) Cells were perfused for 8-10 min, then a control I-V curve was generated $(O)$ by using voltage pulses as described above. The bath was then supplemented with $7.5 \mu \mathrm{M}$ AA, perfusion was continued for $10 \mathrm{~min}$, and the protocol repeated $(\mathbf{O})$. (c) The same conditions were used as in (b) except cells were first perfused with a bath solution containing $15 \mu \mathrm{M}$ AACOCF $\left(\mathrm{O}_{3}\right)$, and then in the presence of both $15 \mu \mathrm{M} \mathrm{AACOCF}$ and $7.5 \mu \mathrm{M} \mathrm{AA}(\mathbf{O})$. For better comparability of the results obtained on the same cell before and after stimulation, data are expressed as the percentage of the current observed at $+60 \mathrm{mV}$ without $\mathrm{AA}$ (taken as $100 \%$ ). The $100 \%$ value corresponded to $7.28 \pm 1.63 \mathrm{pA} / \mathrm{pF}$ and $7.48 \pm 2.25 \mathrm{pA} / \mathrm{pF}$ respectively for untreated and $\mathrm{AACOCF}$ - $\mathrm{pretreated}$ cells. Data are means \pm S.E.M. of four cells from three different animals.

same cells before and after stimulation, the values are expressed as the percentage of the current measured at $+60 \mathrm{mV}$ in the absence of AA (100\%). Figure 3(b) illustrates that perfusing the cells with $7.5 \mu \mathrm{M}$ AA markedly stimulated the currents, in agreement with previous reports [14,20]. (This concentration of AA was chosen because it elicited a comparable stimulation of the current in macrophages as the agonists fMLP and PMA, induced in the $\mathrm{H}^{+}$efflux of neutrophils under similar conditions, i.e. at $\mathrm{pH}_{\mathrm{i}} 6.8$ and at near-zero potentials.) In the following experiments, cells were first perfused with the bath solution containing $15 \mu \mathrm{M} \mathrm{AACOCF}$, followed by a perfusion with $15 \mu \mathrm{M}$ AACOCF ${ }_{3}$ plus $7.5 \mu \mathrm{M}$ AA. Similarly to our observation at $\mathrm{pH}_{\mathrm{i}} 6.0$ (Figure 3a), $\mathrm{AACOCF}_{3}$ did not change the amplitude of the currents at $\mathrm{pH}_{\mathrm{i}} 6.8$ (compare the plots with open symbols on Figures $3 \mathrm{~b}$ and $3 \mathrm{c}$ ). This indicates that neither the voltage dependence nor the $\mathrm{pH}_{\mathrm{i}}$ dependence of the basal currents is affected by the drug. Furthermore, AA was capable of markedly stimulating the conductance also in the presence of $\mathrm{AACOCF}_{3}$ (Figure 3c). The magnitude of this stimulation was very similar at voltages above $15 \mathrm{mV}$ (e.g. at $60 \mathrm{mV}$ the current increased to $225 \pm 24 \%$ versus $208 \pm 37 \%$ respectively in the presence of AA alone or $\mathrm{AACOCF}_{3}$ plus AA). However, $\mathrm{AACOCF}_{3}$ reduced somewhat the AA-triggered stimulation in the vicinity of the voltage threshold of the currents. At $0 \mathrm{mV}$ the activation was 4.2fold versus 2.9-fold in the absence or presence of $\mathrm{AACOCF}_{3}$ respectively. These results suggest that $\mathrm{AACOCF}_{3}$ might modestly reduce the AA-induced shift in the voltage-dependence of the $\mathrm{H}^{+}$channel. Taken together, we conclude that a direct interaction between $\mathrm{AACOCF}_{3}$ and the putative lipid-binding site(s) of the $\mathrm{H}^{+}$channel may contribute to the inhibitory effect of the drug. Such an action alone, however, is probably insufficient to account for the complete inhibition of $\mathrm{H}^{+}$efflux that is observed in stimulated neutrophils.

Irrespective of the relative contribution of the indirect and possible direct effects, these observations are the best indication so far that the agonist-induced activation of the channel is mediated through the liberation of a lipid messenger that in turn may act directly on the conductance.

\section{Does $\mathrm{AACOCF}_{3}$ influence NADPH oxidase or other pH-regulatory systems?}

Having established that $\mathrm{AACOCF}_{3}$ is a potent inhibitor of the activation of the $\mathrm{H}^{+}$conductance, it was tempting to use this agent as a tool to assess whether the $\mathrm{H}^{+}$channel really opens during physiological activation (i.e. in a $\mathrm{Na}^{+}$-based medium, in the absence of ionophores and without artificial cytoplasmic acidification and depolarization). The drug, however, can only be used for this purpose if it does not affect other $\mathrm{H}^{+}$-generating or -eliminating mechanisms. The huge acid production during the respiratory burst is due to the operation of NADPH oxidase $[1,2]$. Therefore we determined the effect of $\mathrm{AACOCF}_{3}$ on superoxide production in neutrophils. $\mathrm{AACOCF}_{3}$ added alone did not provoke superoxide production (results not shown). The PMA-induced response was $43.9 \pm 2.7$ and $50.6 \pm 9.2 \mathrm{nmol}$ $\mathrm{O}_{2}^{-} / 10 \mathrm{~min} / 10^{6}$ cells $(n=3)$ in the absence and presence of $30 \mu \mathrm{M} \mathrm{AACOCF}_{3}$ respectively. With fMLP as a stimulus, superoxide generation was $12.6 \pm 6.2$ and $10.8 \pm 1.14 \mathrm{nmol}$ $\mathrm{O}_{2}^{-\bullet} / 10 \mathrm{~min} / 10^{6}$ cells in control and $\mathrm{AACOCF}_{3}$-treated neutrophils respectively $(n=3)$. Thus $\mathrm{AACOCF}_{3}$ failed to affect 


\section{Table 2 Effect of $\mathrm{AACOCF}_{3}$ on the superoxide production of neutrophils}

Cells were suspended in $\mathrm{Na}^{+}$medium supplemented with $0.1 \%$ BSA plus $100 \mu \mathrm{M}$ cytochrome $C$ and incubated for $10 \mathrm{~min}$ in the absence or presence of the indicated concentrations of $\mathrm{AACOCF}_{3}\left(\left[\mathrm{AACOCF}_{3}\right]\right)$. The neutrophils were then stimulated with fMLP $(1 \mu \mathrm{M})$ or PMA $(10 \mathrm{nM})$ for $10 \mathrm{~min}$ and the amount of superoxide generated was determined by spectrophotometry as the superoxide-dismutase-dependent cytochrome $c$ reduction. Data are means \pm S.E.M. for four different experiments.

\begin{tabular}{ccc}
\hline & \multicolumn{2}{l}{$\begin{array}{l}\text { Superoxide production } \\
\left(\mathrm{nmol} / 10 \mathrm{~min} / 10^{6} \mathrm{cells}\right)\end{array}$} \\
\cline { 2 - 3 }$\left[\mathrm{AACOCF}_{3}\right](\mu \mathrm{M})$ & $\mathrm{fMLP}$ & $\mathrm{PMA}$ \\
\hline & & \\
\hline 15 & $16 \pm 0.8$ & $50 \pm 5.4$ \\
30 & $20.8 \pm 2.2$ & $59.2 \pm 4.3$ \\
60 & $20.2 \pm 2.07$ & $61.2 \pm 10.4$ \\
& $21.27 \pm 6.2$ & $45.24 \pm 6.7$ \\
\hline
\end{tabular}

superoxide production at a concentration where it caused $>$ $90 \%$ inhibition of the activation of the $\mathrm{H}^{+}$efflux (see Figure 1). We determined $\mathrm{O}_{2}^{-}$generation at various concentrations of $\mathrm{AACOCF}_{3}$, under the same conditions (i.e. using the $0.1 \%$-BSAcontaining medium) that we applied for the measurement of AA liberation. Table 2 shows that $\mathrm{AACOCF}_{3}$ inhibited neither the fMLP- nor the PMA-induced free-radical generation, even at $60 \mu \mathrm{M}$, where the drug abolished the AA release triggered by either stimulus (Table 1). This result was rather surprising since exogenously applied AA is a well-known stimulator of the oxidase [42,43], and non-selective blockers of PLA 2 (like bromophenacyl bromide) can completely suppress superoxide generation $[23,44]$. These earlier findings lent credence to the assumption that endogenous AA production is mandatory for oxidase activation [45]. Our results, however, suggest that the activation of $\mathrm{cPLA}_{2}$ and AA release (at least from the pool labelled under our conditions) are not a prerequisite for PKC- or the receptor-mediated superoxide production.

With this information in mind we continued the systematic analysis of the possible effect(s) of the drug on other $\mathrm{pH}_{\mathrm{i}}$ regulatory components. The major $\mathrm{H}^{+}$transporter in neutrophils is the NHE. The predominant contribution of this system to the $\mathrm{pH}_{\mathrm{i}}$ changes observed in stimulated neutrophils is demonstrated in Figure 4(a). Under control conditions (upper trace) PMA elicited a transient acidification, which is followed by a prolonged, larger alkalinization $(\geqslant 0.2 \mathrm{pH})$. The $\mathrm{pH}_{\mathrm{i}}$ profile was entirely different in the presence of EIPA, a specific blocker of the NHE (lower trace). Under these conditions PMA induced a large net acidification $(\geqslant 0.5 \mathrm{pH})$ since the cells were not able to get rid of the vast amount of protons generated by NADPH oxidase. It was therefore essential to test the effect of $\mathrm{AACOCF}_{3}$ on the NHE. To this end we followed the $\mathrm{Na}^{+}$-induced $\mathrm{pH}_{\mathrm{i}}$ changes in resting cells. These measurements were carried out in a choline medium where, due to the high membrane potential, the $\mathrm{H}^{+}$ gradient is inward, excluding $\mathrm{H}^{+}$release through the channel. Figure 4(b) shows that addition of $\mathrm{Na}^{+}$triggered a sizeable alkalinization that was completely EIPA-inhibitable, proving that it was entirely mediated by the NHE. $\mathrm{Zn}^{2+}$ and other heavy metals, the only known blockers of the $\mathrm{H}^{+}$channel, markedly inhibited the NHE as well (with $50 \mu \mathrm{M} \mathrm{ZnCl}_{2}$ the reduction was $74.2 \pm 2.45 \%, n=4$; Figure $4 \mathrm{~b}$ ) and therefore are not appropriate to approach the physiological contribution of the channel. In sharp contrast, AACOCF ${ }_{3}$ had no effect on $\mathrm{Na}^{+} / \mathrm{H}^{+}$ exchange: in the absence and presence of the drug the initial rates of $\mathrm{Na}^{+}$-induced $\mathrm{pH}_{\mathrm{i}}$ changes were respectively $0.192 \pm 0.04$ $\Delta \mathrm{pH} / \min (n=4)$ and $0.195 \pm 0.047 \Delta \mathrm{pH} / \min (n=4)$. Though (a)

$\mathrm{Na}^{+}$medium

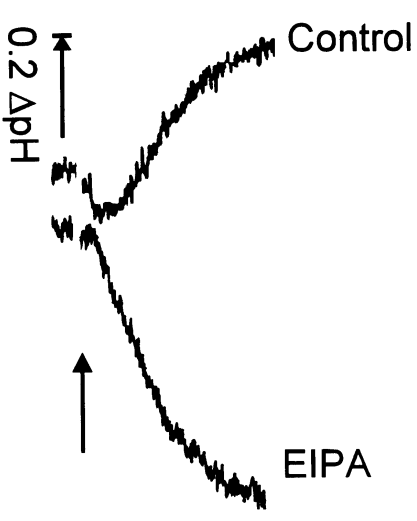

PMA (b)

Choline medium (c)

\section{$\mathrm{Na}^{+}$medium}

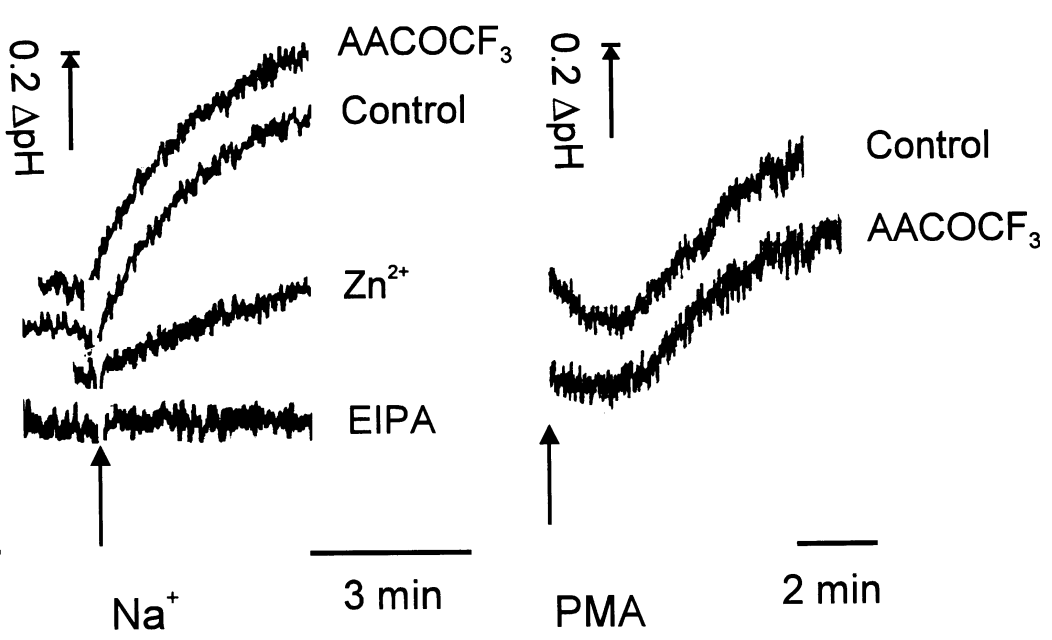

Figure 4 Operation of the NHE is not altered by $\mathrm{AACOCF}_{3}$

(a) BCECF-loaded neutrophils $\left(2 \times 10^{6}\right)$ were suspended in $\mathrm{Na}^{+}$medium and stimulated with $20 \mathrm{nM}$ PMA (indicated by the arrow) in the presence or absence of $4 \mu \mathrm{M}$ EIPA. (b) Neutrophils were suspended in choline medium and $10 \mathrm{mM} \mathrm{NaCl}$ was applied where indicated (by the arrow). Cells were pretreated with $15 \mu \mathrm{M} \mathrm{AACOCF}_{3}$ (10 min), $50 \mu \mathrm{M}$ ZnCl or $5 \mu \mathrm{M}$ EIPA. (c) Lymphocytes $\left(5 \times 10^{6}\right)$ were suspended in $\mathrm{Na}^{+}$medium preincubated with or without $15 \mu \mathrm{M} \mathrm{AACOCF}$ for 5 min and then stimulated with $100 \mathrm{nM}$ PMA (indicated by the arrow). For the sake of clarity traces were shifted vertically. Recordings are representative of four different experiments. 
(a)

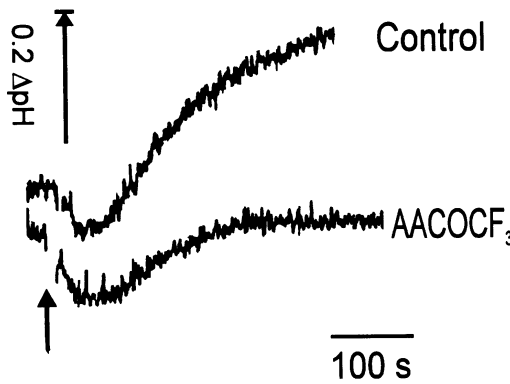

fMLP (b)

(c)

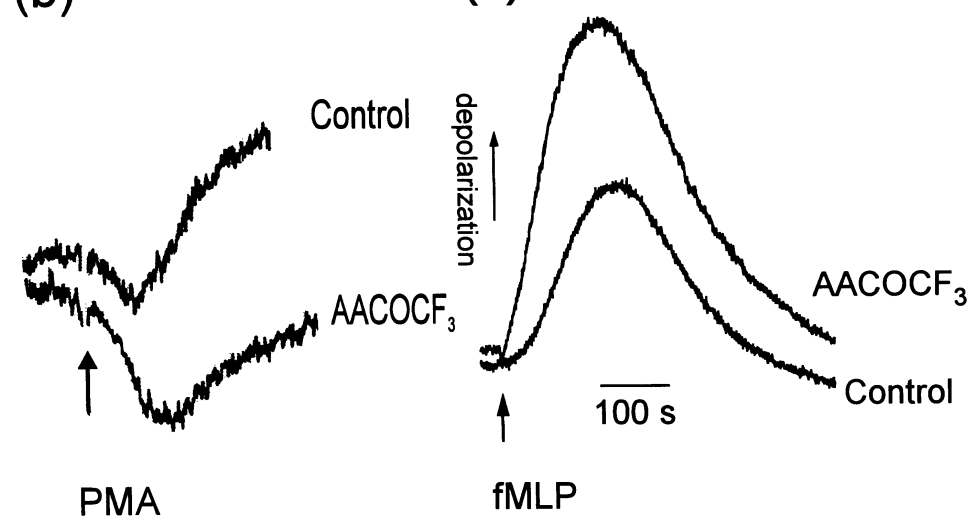

Figure 5 Contribution of the activated $\mathbf{H}^{+}$conductance to the stimulus-induced changes in $\mathrm{pH}_{\mathrm{i}}$ and membrane potential

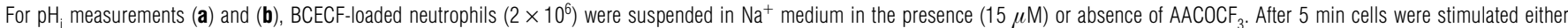
by $1 \mu \mathrm{M}$ fMLP (a) or $20 \mathrm{nM}$ PMA (b) (indicated by the arrows). Membrane potential changes (c) were detected in $\mathrm{Na}^{+}$medium supplemented with $200 \mathrm{nM}$ DiSBAC ${ }_{2}(3)$. Other conditions were as in (a) except that $20 \mathrm{nM} \mathrm{fMLP}$ was applied (indicated by the arrow). To improve comparability the traces shown were shifted vertically. Recordings are representative of four different experiments.

inert on the antiporter under resting conditions, $\mathrm{AACOCF}_{3}$ might interfere with the stimulus-induced activation of it. This possibility was examined in peripheral lymphocytes (Figure 4c). These cells are lacking a functional oxidase or a PKC-dependent $\mathrm{H}^{+}$channel [36], but contain the same PKC-sensitive NHE as neutrophils [46]. The rate of alkalinization induced by $100 \mathrm{nM}$ PMA was $0.066 \pm 0.022 \Delta \mathrm{pH} / \mathrm{min}(n=3)$ and $0.063 \pm 0.026$ $\Delta \mathrm{pH} / \mathrm{min}(n=3)$ in the absence and presence of $\mathrm{AACOCF}_{3}$ respectively. Thus the PMA-provoked alkalinization remained unaffected, suggesting that $\mathrm{AACOCF}_{3}$ did not alter NHE activation.

Another system that may potentially free the cells from the deleterious acid is a bafilomycin-sensitive V-type ATPase. However, addition of bafilomycin did not change the profile of $\mathrm{H}^{+}$ movements (results not shown), indicating that under our conditions the contribution of the ATPase is negligible if present at all. This finding is consistent with earlier reports [5,47] and with the fact that the ATPase becomes inserted into the plasma membrane from a vacuolar source, a process that becomes easily detectable only in the presence of cytochalasins [21].

Does the $\mathrm{H}^{+}$channel open during stimulation of neutrophils under physiological conditions?

In the light of our data showing that $\mathrm{AACOCF}_{3}$ inhibits the activation of the $\mathrm{H}^{+}$channel in neutrophils, while it does not interfere with the oxidase or with other $\mathrm{H}^{+}$transporters, we could use the drug to assess the contribution of the channel in stimulus-induced $\mathrm{pH}_{\mathrm{i}}$ changes. Figures 5(a) and 5(b) show that in the presence of $\mathrm{AACOCF}_{3}$ the $\mathrm{pH}_{\mathrm{i}}$ responses of the cells stimulated with fMLP or PMA are significantly different from the corresponding controls. With the AA analogue present, the amplitude of the initial acidification was approx. 2-fold larger, whereas the subsequent alkalinization was much slower and smaller. In most cases the $\mathrm{pH}_{\mathrm{i}}$ could not increase above the resting level. A further indication of the activation of the channel is that in the presence of EIPA and bafilomycin, the addition of $\mathrm{AACOCF}_{3}$ could still increase the initial rate of acidification (results not shown). This clearly implies that upon stimulation an $\mathrm{AACOCF}_{3}$-sensitive $\mathrm{H}^{+}$pathway must have been operating and this route continued to work even when the NHE and the $\mathrm{H}^{+}$ ATPase were completely blocked.

If the $\mathrm{H}^{+}$conductance opens during physiological activation of the cell, it is expected to limit the oxidase-induced depolarization. Conversely, a more pronounced depolarization should occur if the activation of this pathway is prevented. Figure 5(c) shows that this predicted effect could indeed be observed. The fMLPinduced depolarization was on average 5-fold faster and substantially larger and longer lasting in $\mathrm{AACOCF}_{3}$-treated neutrophils than in the controls. These observations strongly suggest that during cell activation in a physiological environment the rheogenic $\mathrm{H}^{+}$pathway of neutrophils does open, and this event contributes to the overall $\mathrm{pH}_{\mathrm{i}}$ changes and modulates the magnitude of the membrane potential.

\section{DISCUSSION}

Our work demonstrates that both the receptor-agonist-induced and the phorbol-ester-promoted activation of the $\mathrm{H}^{+}$channel of neutrophils can be completely abolished by using $\mathrm{AACOCF}_{3}$, a newly developed selective inhibitor of $\mathrm{CPLA}_{2}$. This compound was documented to inhibit the $85-\mathrm{kDa}_{\mathrm{cPLA}}$ both in vitro [32] and in vivo in a variety of different cell types, including platelets [33,34] and Madin-Darby canine kidney cells [40]. In contrast, it did not affect the activity of the 14-kDa secretory form of the enzyme [32,34]. Several observations suggest that the inhibitory effect of $\mathrm{AACOCF}_{3}$ on the activation of the channel is related to its inhibitory action on CPLA $_{2}$. (1) Both fMLP and PMA were reported to induce the phosphorylation and activation of $\mathrm{CPLA}_{2}$ in phagocytes [30,48]. (2) Both of these stimulants triggered the release of AA from neutrophils ([18,22,26,39] and Table 1) and this effect was suppressed by $\mathrm{AACOCF}_{3}$ (Table 1). (3) Other signalling pathways that have been implicated in the regulation of the $\mathrm{H}^{+}$translocator $[10,17]$ were not affected by the compound: the fMLP-evoked tyrosine phosphorylation and $\mathrm{Ca}^{2+}$ signal, as well as the phorbol-ester-elicited PKC stimulation remained intact in the presence of $\mathrm{AACOCF}_{3}$ (Figure 2). (4) Detailed electrophysiological examinations have verified that the drug does not alter the voltage- and $\mathrm{pH}_{\mathrm{i}}$-dependent activation of the pathway, and therefore is not a blocker of the $\mathrm{H}^{+}$conductance itself (Figure 3). These findings, together with our earlier obser- 
vations showing that exogenously added arachidonate strongly facilitates the $\mathrm{H}^{+}$conductance $[14,19,20]$, substantiate the notion that this fatty acid, probably liberated by the activated $\mathrm{CPLA}_{2}$, is a physiological mediator that directly controls the $\mathrm{H}^{+}$channel. Recent data obtained on other cell types favour this interpretation. The $\mathrm{H}^{+}$conductance was shown to be present in the membrane of peripheral lymphocytes. However, in these cells only arachidonate but not phorbol esters can stimulate the conductance [36]. This phenomenon may now be perfectly explained on the basis of a recent observation by Gilbert et al. [49] who found that only immature, but not mature, B- and Tcells expressed cPLA $_{2}$.

There is circumstantial pharmacological evidence that $\mathrm{SPLA}_{2}$ is not necessarily involved in this process. Manoalide and scalaradial, two selective SPLA $_{2}$ inhibitors, failed to affect the PMA-promoted rheogenic $\mathrm{H}^{+}$release (results not shown). These agents, however, markedly reduced the effect of fMLP. This is probably attributable to the fact that both compounds are known to seriously perturb the early steps of the receptormediated signalling, e.g. agonist binding and PLC activation [22]. In fact both of them substantially decreased and distorted the fMLP-triggered $\mathrm{Ca}^{2+}$ signal.

A somewhat unexpected finding of this study was that $\mathrm{AACOCF}_{3}$ could entirely abolish AA release triggered by fMLP or PMA. This fact suggests that most, if not all, of the AA released and detected under our conditions (labelling only the rapidly exchanging pool, with short stimulation and no cytochalasin present) was mobilized by cPLA $_{2}$. This result is consistent with recent reports [26,39]. Balsinde and Dennis [50] have suggested that in $\mathrm{P} 338 \mathrm{D}$ macrophages a sequential activation and potential cross-talk exists between $\mathrm{cPLA}_{2}$ and $\mathrm{sPLA}_{2}$. First cPLA $_{2}$ becomes activated and transiently liberates AA, which is then used to stimulate the operation of $\mathrm{SPLA}_{2}$. If a similar coupling between the two phospholipases is present also in neutrophils, inhibition of $\mathrm{CPLA}_{2}$ might reduce the $\mathrm{SPLA}_{2}-$ mediated fatty acid liberation as well.

An alternative but not at all exclusive suggestion for the mechanism through which $\mathrm{AACOCF}_{3}$ may act, is that it could compete with arachidonate for binding to the $\mathrm{H}^{+}$channel. This assumption is based on our finding that at moderate depolarizations the AA-induced activation of the channel was somewhat smaller in the presence of the inhibitor. Although this effect was weak, at present it is not possible to predict its relative contribution to the overall inhibition since no data are available on the effective concentrations of arachidonate or $\mathrm{AACOCF}_{3}$ in the vicinity of the $\mathrm{H}^{+}$channel. Irrespective of its magnitude, however, such an effect clearly signifies that there must be lipidbinding regulatory site(s) on the putative channel that, upon stimulation, should be occupied by an endogenously generated ligand.

The first suggested role for the $\mathrm{H}^{+}$channel was that it may serve as a charge-compensating device for the electrogenic NADPH oxidase [51]. The relationship between the two systems was suspected to be so firm that Henderson et al. proposed that the channel is one of the cytochrome subunits of the oxidase itself [52]. Although this notion was thoroughly challenged by us [36,53] and others [54], the striking similarity between the regulation of the oxidase and the channel seemed undebatable. Both were, for example, stimulated by arachidonate, and

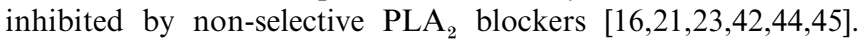
Much to our surprise the response of the two systems to $\mathrm{AACOCF}_{3}$ was entirely different: at concentrations where the activation of the channel and mobilization of AA were practically abolished, superoxide generation remained essentially unaffected (Table 2). This implies that activation of $\mathrm{CPLA}_{2}$ (and perhaps the liberation of AA) is not a prerequisite to turning on NADPH oxidase. In agreement with this notion, Roberts et al. found that $\mathrm{PLA}_{2}$ activity is involved in FMLP-induced superoxide generation only in cells primed with cytokines [26].

It was previously suggested that charge translocation through the channel is a rate-limiting factor in superoxide production [51]. Our finding that $\mathrm{AACOCF}_{3}$ did not decrease superoxide production seems to be in an apparent contradiction to this concept. However, it is worth recalling here that only the AAinduced activation, but not the basal activity of the channel, is modified by the AA analogue. This background activity in an acid-producing depolarized cell may be enough to account for the necessary charge compensation. Previous calculations suggest [13], and new, direct measurements show [55], that the oxidasegenerated current is very small $(\approx 2 \mathrm{pA} /$ cell $)$; thus a minor fraction of the maximal $\mathrm{H}^{+}$current can be sufficient to compensate for it. In addition, the enzyme was shown to be capable of pumping out electrons against large unfavourable electric gradients.

Our final point regards the physiological role of the $\mathrm{H}^{+}$conductance. Taking advantage of the fact that $\mathrm{AACOCF}_{3}$ proved not to be affecting any other $\mathrm{H}^{+}$transporter or their activation, we could show for the first time that the $\mathrm{H}^{+}$channel is involved in the characteristic $\mathrm{pH}_{\mathrm{i}}$ changes of intact neutrophils stimulated under physiological conditions (Figures 5a and 5b). This system definitively opens up and helps the NHE to eliminate $\mathrm{H}^{+}$equivalents during cell activation. In addition, it reduces the oxidase-induced depolarization and promotes the repolarization of phagocytes (Figure 5c). These membrane-potential changes might be important for the control of other voltage-sensitive processes, e.g. the modulation of the capacitive $\mathrm{Ca}^{2+}$ influx.

In summary, we propose that $\mathrm{cPLA}_{2}$ plays an essential role in the activation of the $\mathrm{H}^{+}$channel. However, we conclude that this enzyme may not necessarily be involved in the regulation of NADPH oxidase. We suggest that receptor-mediated stimuli activate the $\mathrm{H}^{+}$conductance by liberating AA and perhaps other lipid mediators. The stimulated $\mathrm{H}^{+}$conductance contributes to the physiologic $\mathrm{pH}_{\mathrm{i}}$ homeostasis and modulates membranepotential changes of neutrophils.

We are indebted to Professor András Spät for the opportunity to use the patch-clamp set-up and the fluorimeter, to Professor Anna Faragó, Dr. Györgyi Farkas and Ms. Erzsébet Bander for their valuable help in the PKC activity measurements, to Professor József Mandl for providing the experimental animals, to Dr. Miklós Geiszt for his contribution in the $\left[\mathrm{Ca}^{2+}\right]_{\mathrm{i}}$ determinations and to Ms. Erzsébet Seres-Horváth, Ms. Edit Fedina and Ms. Klára Somogyi for excellent technical assistance. Experimental work was financially supported by grants from the National Research Fund (OTKA F 019715, T 013097, T 014842, T-14649), Hungarian Ministry of Health, and from PHARE-Accord (H 9112-0295).

\section{REFERENCES}

1 Nanda, A. and Grinstein, S. (1991) Proc. Natl. Acad. Sci. U.S.A. 88, 10816-10820

2 Grinstein, S. and Furuya, W. (1986) Am. J. Physiol. 251, C55-C65

3 Nanda, A. and Grinstein, S. (1991) Cell. Physiol. Biochem. 1, 65-75

4 Grinstein, S. and Furuya, W. (1986) Am. J. Physiol. 250, C283-C291

5 Nanda, A., Brumell, J. H., Nordstrom, T., Kjeldsen, L., Sengelov, H., Borregaard, N. Rotstein, O. D. and Grinstein, S. (1996) J. Biol. Chem. 271, 15963-15970

6 DeCoursey, T. E. and Cherny, V. V. (1994) J. Membr. Biol. 141, 203-223

7 Lukács, G. L., Kapus, A., Nanda, A., Romanek, R. and Grinstein, S. (1993) Am. J. Physiol. 265, C3-C14

8 Henderson, L. M., Chappell, J. B. and Jones, O. T. (1987) Biochem. J. 246, 325-329

9 Henderson, L. M., Chappell, J. B. and Jones, O. T. (1988) Biochem. J. 251, 563-567

10 Kapus, A., Szászi, K. and Ligeti, E. (1992) Biochem. J. 281, 697-701

11 Nanda, A., Grinstein, S. and Curnutte, J. T. (1993) Proc. Natl. Acad. Sci. U.S.A. 90 760-764

12 Demaurex, N., Grinstein, S., Jaconi, M., Schlegel, W., Lew, D. P. and Krause, K. H. (1993) J. Physiol. (London) 466, 329-344 
13 Kapus, A., Romanek, R., Qu, A. Y., Rotstein, O. D. and Grinstein, S. (1993) J. Gen. Physiol. 102, 729-760

14 DeCoursey, T. E. and Cherny, V. V. (1993) Biophys. J. 65, 1590-1598

15 Schumann, M. A., Leung, C. C. and Raffin, T. A. (1995) J. Biol. Chem. 270, 13124-13132

16 Suszták, K., Káldi, K., Kapus, A. and Ligeti, E. (1995) FEBS Lett. 375, 79-82

17 Nanda, A. and Grinstein, S. (1995) J. Cell. Physiol. 165, 588-599

18 Cockcroft, S. (1992) Biochim. Biophys. Acta 1113, 135-160

19 Henderson, L. M. and Chappell, J. B. (1992) Biochem. J. 283, 171-175

20 Kapus, A., Romanek, R. and Grinstein, S. (1994) J. Biol. Chem. 269, 4736-4745

21 Kapus, A., Suszták, K. and Ligeti, E. (1993) Biochem. J. 292, 445-450

22 Barnette, M. S., Rush, J., Marshall, L. A., Foley, J. J., Schmidt, D. B. and Sarau, H. M. (1994) Biochem. Pharmacol. 47, 1661-1667

23 Henderson, L. M., Chappell, J. B. and Jones, 0. T. (1989) Biochem. J. 264, 249-255

24 Dennis, E. A. (1994) J. Biol. Chem. 269, 13057-13060

25 Rodewald, E., Tibes, U., Maass, G. and Scheuer, W. (1994) Eur. J. Biochem. 223, 743-749

26 Roberts, P. J., Williams, S. L. and Linch, D. C. (1996) Br. J. Haematol. 92, 804-814

27 Nasmith, P. E. and Grinstein, S. (1987) J. Biol. Chem. 262, 13558-13566

28 Sundler, R., Winstedt, D. and Wijkander, J. (1994) Biochem. J. 301, 455-458

29 Grinstein, S., Smith, J. D., Onizuka, R., Cheung, R. K., Gelfand, E. W. and Benedict, S. (1988) J. Biol. Chem. 263, 8658-8665

30 Durstin, M., Durstin, S., Molski, T. F., Becker, E. L. and Sha'afi, R. I. (1994) Proc. Natl. Acad. Sci. U.S.A. 91, 3142-3146

31 Wijkander, J. and Sundler, R. (1991) Eur. J. Biochem. 202, 873-880

32 Street, I. P., Lin, H. K., Laliberte, F., Ghomashchi, F., Wang, Z., Perrier, H., Tremblay, N. M., Huang, Z., Weech, P. K. and Gelb, M. H. (1993) Biochemistry 32, 5935-5940

33 Riendeau, D., Guay, J., Weech, P. K., Laliberte, F., Yergey, J., Li, C., Desmarais, S., Perrier, H., Liu, S., Nicoll Griffith, D., et al. (1994) J. Biol. Chem. 269, 15619-15624

34 Bartoli, F., Lin, H. K., Ghomashchi, F., Gelb, M. H., Jain, M. K. and Apitz Castro, R. (1994) J. Biol. Chem. 269, 15625-15630
35 Geiszt, M., Káldi, K., Szeberényi, J. B. and Ligeti, E. (1995) Biochem. J. 305 525-528

36 Káldi, K., Szászi, K., Suszták, K., Kapus, A and Ligeti, E. (1994) Biochem. J. 301, 329-334

37 Brumell, J. H. and Grinstein, S. (1994) Am. J. Physiol. 267, C1574-C1581

38 Buday, L., Seprödi, J., Farkas, G., Mészaros, G., Romhányi, T., Bánhegyi, G., Mandl, J., Antoni, F and Faragó, A. (1987) FEBS Lett. 223, 15-19

39 Jacobson, P. B. and Schrier, D. J. (1993) J. Immunol. 151, 5639-5652

40 Xing, M. B. and Insel, P. A. (1996) J. Clin. Invest. 97, 1302-1310

41 Ding, J. and Badwey, J. A. (1993) J. Biol. Chem. 268, 5234-5240

42 Bromberg, Y. and Pick, E. (1983) Cell. Immunol. 79, 240-252

43 Badwey, J. A., Curnutte, J. T., Robinson, J. M., Berde, C. B., Karnovsky, M. J. and Karnovsky, M. L. (1984) J. Biol. Chem. 259, 7870-7877

44 Dana, R., Malech, H. L. and Levy, R. (1994) Biochem. J. 297, 217-223

45 Henderson, L. M., Moule, S. K. and Chappell, J. B. (1993) Eur. J. Biochem. 211, 157-162

46 Rosskopf, D., Fromter, E. and Siffert, W. (1993) J. Clin. Invest. 92, 2553-2559

47 Nanda, A., Gukovskaya, A., Tseng, J. and Grinstein, S. (1992) J. Biol. Chem. 267, 22740-22746

48 Wijkander, J. and Sundler, R. (1989) Biochem. Biophys. Acta 1010, 78-87

49 Gilbert, J. J., Stewart, A., Courtney, C. A., Fleming, M. C., Reid, P., Jackson, C. G., Wise, A., Wakelam, M. J. O. and Harnett, M. M. (1996) J. Immunol. 156, 2054-2061

50 Balsinde, J. and Dennis, E. A. (1996) J. Biol. Chem. 271, 6758-6765

51 Henderson, L. M., Chappell, J. B. and Jones, O. T. (1988) Biochem. J. 255, 285-290

52 Henderson, L. M., Banting, G. and Chappell, J. B. (1995) J. Biol. Chem. 270 5909-5916

53 Káldi, K., Szászi, K., Koncz, G., Suszták, K. and Ligeti, E. (1996) FEBS Lett. 381 156-160

54 Nanda, A., Romanek, R., Curnutte, J. T. and Grinstein, S. (1994) J. Biol. Chem. 269 , 27280-27285

55 Schrenzel, J., Lew, D. P. and Krause, K.-H. (1996) Eur. J. Clin. Invest. 26, 175

Received 3 December 1996/21 February 1997; accepted 18 March 1997 